UDC 82.09

DOI https://doi.org/10.24919/2308-4863/40-2-17

Tetiana KONDRATIEVA, orcid.org/0000-0003-2092-051X

Ph. D. in Philology, Associate Professor, Associate Professor at the Department of English Philology and Methods of Teaching English Ternopil Volodymyr Hnatiuk National Pedagogical University

(Ternopil, Ukraine) kondratievatb@gmail.com

Larysa KUTSA, orcid.org/0000-0003-4877-9626 Ph. D. in Philology, Associate Professor, Associate Professor at the Department of Philological Disciplines for Primary Education Ternopil Volodymyr Hnatiuk National Pedagogical University (Ternopil, Ukraine) larkutsa@ukr.net

\title{
LIFE WRITING ABOUT CHILDHOOD AS NARRATION OF IDENTITY FORMATION EXPERIENCE
}

The article deals with the study of autofiction as a variation of life writing about childhood. The major researches have been analyzed and the key stages in genre formation have been defined, beginning with Enlightenment images up to XXI'st century. New tendencies in life writing for children have been mentioned. Peculiarities of autofiction as a genre have been singled out: grammatical features (first or third person narration and tense usage), narration structures (distant narration), thematic scope (image of ideal child and childhood, trauma, nostalgia, identity formation experience). It has been emphasized that autobiographical literature about childhood serves as the mirror of social and cultural codes of an epoch and reflects interaction modes between children and adults, as well as between children and the world. The article is focused on analyzing the peculiarities of author's self-reflection and retrospection from the adult point of view. This can be achieved through author-narrator-character image blending. However, in autofiction, unlike classical autobiography, the blending is partial with enough space for the author to add fiction to the life writing. The research has been based on the analysis of Ulf Stark's works in the identity formation paradigm with the focus on the author's representation of his way to literature. It has been noticed, that ironic attitude to the events described in his works is the stylistic peculiarity of Ulf Stark's autofiction for children, which can be explained by the author's intention to show the lack of experience of his past-self in childhood. Thus, the following key factors have been defined: time and space markers of childhood, memory metaphors, life changing occasions and relationships. Concept of home and the idea of leaving home as a symbol of threshold between childhood and adult life has been discussed. Peculiar spaces, such as cave and tree house, have been studied. Role of parents, friends as well as first love experience in writer's identity formation has been outlined. Special attention has been paid to presenting the significance of imagination typical of child consciousness and its crucial role in formation of future writer's talent and creativity.

Key words: autobiography, autofiction, childhood, memory metaphors, imagination.

Тетяна КОНДРАТЬСВА, orcid.org/0000-0003-2092-051X кандидат філологічних наук, дочент,

доцент кафедри англійської філології та методики навчання англійської мови Тернопільського начіонального педагогічного університету імені Володимира Гнатюка (Тернопіль, Україна) kondratievatb@gmail.com

Лариса КУЦА, orcid.org/0000-0003-4877-9626 кандидат філологічних наук, дочент, доиент кафедри філологічних дисциплін для початкової освіти Тернопільського національного педагогічного університету імені Володимира Гнатюка (Тернопіль, Україна) larkutsa@ukr.net

\section{ЖИТТЕПИС ДИТИНСТВА ЯК НАРАЦІЯ ПРО ДОСВІД ФОРМУВАННЯ ІДЕНТИЧНОСТІ}

У статті досліджується художня автобіографія як варіація життєпису про дитинство. Проаналізовано основні дослідження цієї проблеми та простежено визначальні стадії розвитку жанру, починаючи від образів дитини в епоху просвітництва і до ХХІ століття. Зазначено нові тенденції в жанрі життєпису для дітей. Вио- 
кремлено особливості жанру художньої автобіографії: граматичні ознаки (розповідь від першої або третьої особи, використання певних часових форм), наративні структури (дистанційована нарація), тематика (образ ідеальної дитини та дитинства, травма, ностальгія, досвід формування ідентичності). Наголошено, щзо автобіографічна література про дитинство слугує дзеркалом сочіальних та культурних кодів епохи, яке відображає способи взаємодії між дітьми та дорослими, а також між дітьми та світом. Увага зосереджена на особливостях авторської саморефлексії та ретроспекиії з позииії дорослого. Це досягається завдяки злиттю образу автора-наратора-персонажа. Проте в художній автобіографії, на відміну від класичної автобіографії, ие злиття часткове, автор має досить простору для додавання художніх деталей до життєпису. Дослідження базується на аналізі творів Ульфа Старка в парадигмі досвіду формування ідентичності, з акиентом на авторській презентації його шляху в літературу. Відзначено, щзо стилістичною особливістю художньої автобіографії Ульфа Старка є іронічне ставлення до подій, описаних у його творах, щуо можна потрактувати як авторську інтенцію зобразити недосвідченість його ж самого в минулому, у дитинстві. Отже, були визначені такі ключові чинники: хронотопні маркери дитинства, метафори пам'яті, події та стосунки, які змінили життя. Описано концепт дому й ідею покидання дому як символ порога між дитинством та дорослим життям. Досліджено особливі простори, як-от будинок на дереві та печера. Окреслено роль батьків, друзів, а також досвіду першого кохання у формуванні ідентичності автора. Особлива увага приділяється презентації важливості уяви, характерної для дитячої свідомості, ї̈ вирішальній ролі у формуванні таланту та творчості майбутнього письменника.

Ключові слова: автобіографія, художня автобіографія, дитинство, метафори пам'яті, уява.

Problem statement. Childhood in autobiographical fiction has often been a subject of interest, both for authors and literary researchers. Attitude to treating childhood and child in fiction was changing in the course of literary process: from minor role or even neglecting, to occupying central position in literature. Genres and features of literary works dedicated to this topic varied and evolved. We may mention memoirs on childhood times, autobiography written by adult authors for adult readers, autobiographies on childhood written by adult authors for young readers, autofiction with modified plots and characters for young readers. These days researchers distinguish new subgenres and ways of presenting autobiography about childhood written by young writers in new modes, such as blogs, videoblogs in social networks, visual stories etc. All these forms of life writing focus on different topics, however, the main message still can be formulated as the depiction of personality growth and development under the influence of various internal and external factors. The dominance and significance of certain factors predetermines the thematic vector of a literary work, thus inspiring literary researches to decode, define and classify them.

Research analysis. Autobiography as a literary genre was studied by many scholars. Among them we must single out $\mathrm{Ph}$. Lejuene, who defined peculiarities of autobiography in European culture of XIX$\mathrm{XX}$ centuries. S. Doubrovsky first used the term autofiction and defined its stylistic peculiarities. Later his ideas were developed by E. S. Bates and A. Hughes et al. Australian researchers K. Cardel and K. Douglas analyze recent tendencies on the genre development in their work "Telling tales: autobiographies of childhood and youth". C. Bacon focuses on some theoretical points concerning formal features of writings about life. In Ukrainian literary studies this problem has been discussed in works by I. Konstankevych, who presented a thorough theoretical analysis of autobiography and its variations and provided numerous illustrations based on Ukrainian authors' works of the first half of the $\mathrm{XX}^{\text {th }}$ century.

The objectives of the article. In our paper we aim at analyzing autofiction by Ulf Stark, a famous Sweddish writer of fiction for children, whose works keep gaining vast popularity in Ukraine, as many of them were translated into Ukrainian and published here. The article will focus on the novels "Then I was simply Ulf" and "My friend Percy, Buffalo Bill and me". A. Bernardini outlines the following key motives of his fiction: "the conflict between freedom and socialization, the longing for adventure, and the development, through constant interaction with one's peers in a deeply homosocial world, of a sense of self and of an idea of manhood" (Bernardini, 2019: 7). However, in our paper we shall focus on peculiarities of Stark's works as an example of autofiction and reflection of the theme of personality formation experience in his literary works. Special attention will be paid to defining key concepts that predetermine the author's creative activity.

Research results discussion. As K. Cardell emphasizes: "The presence (or indeed absence) of childhood in autobiographical writings reveals something of the cultural position of the child within society and culture of the time" (Cardell, 2013: 4). $\mathrm{N}$. Marchenko states, that "by appealing to existing cultural prototypes with the aim to depict personal unique event most realistically and believably, an individual literary is trying to "inscribe" himself or herself into time and space of his or her community. In a life writing we may find not only subjective attitude/impression/experience of a person, but also figure out $\langle\ldots\rangle$ key matrix codes of relationships 
between the world of adults and the world of children typical for a certain epoch" (Marchenko, 2012: 104). $\mathrm{H}$. Lierop-Debrauver traces the shift of focus in literature about childhood. She mentions, that in the second half of the XVIII ${ }^{\text {th }}$ century and the beginning of the XIX ${ }^{\text {th }}$ century image of child has been romanticized by Rousseau, Blake and Wordsworth by ascribing it such features as natural goodness, innocence and creativity. "Innocence was considered to be a positively valued lack of knowledge and experience, intricately connected with a fresh and unique worldview, determined by imagination and an absence of rationalization" (Lierop-Debrauver, 2018: 3). Later fiction, non-fiction and some crossover forms on childhood acquire more didactic character, like in Bildungsroman, which was focused on the growth of the individual. However, in these writings the image of a child growing into adult and improving its personality aimed at reaching perfection and served as a model for a person's development. In the $\mathrm{XX}^{\text {th }}$ and $\mathrm{XX} 1^{\text {st }}$ centuries, however, childhood has attracted interest by itself, which illustrates changes in attitude to childhood and children in cultural paradigm. This shift was determined by the crisis at the turn of the Millennium and evoked two major motives for remembering childhood: trauma and nostalgia. Major focus in trauma narrations were abuse, poverty, wartime issues, discrimination and identity struggles (Cardel, 2013: 2). At the same time, many adult authors of life narration about childhood employ "nostalgic sentimental frames and deploy Bildungsroman-esque structures in ways that are strategically aligned to their adult achievement" (Cardel, 2013: 4). To generalize, we may refer to K. Douglas' definition of autobiography of childhood as "different forms of life writing in which childhood is the central representation and theme" (Douglas, Poletti, 2016: 170).

In our paper, however, we shall focus in the type of autobiography, dedicated to narrating about identity formation experience written by adult author for young readers. $\mathrm{K}$. Cardell mentions, that in this form of autobiography adult writers "retrospectively reimagine their childhood self" (Cardel, 2013: 3). This idea proves the definition by $\mathrm{Ph}$. Lejeune, a prominent autobiography scholar, who views autobiography as a "retrospective prose narrative produced by a real person concerning his own existence, focusing on his individual life, in particular on the development of his personality" (Lejeune, 2001: 257). Ph. Lejeune's autobiographical essays are focused on "the giddy moment, when an idea occurs to a person, that he or she can observe himself or herself with interest, but without narcissistic self-indulgence or masochistic self-damaging" (Lejeune, 2001: 260).
The same idea has been suggested by N. Marchenko, who emphasizes, that "autobiography about childhood is the very source, which allows tracing the way of a person's self-identification, outline key reasons and stimuli for his/her formation as a social and cultural being, as only in childhood memories an individual must evoke the natural state of "I", in which external cultural factors haven't made any imprint yet" (Marchenko, 2012: 92). I. Starovoit uses the word combination "identity growing" to define the first stage of childhood depicted in autofiction (Starovoit, 2004: 180).

In the process of an autobiographical work analysis, axiological aspect acquires its significance: it requires a detailed analysis of content and form in their interconnection, peculiarities of author's individuality and reader's perception tendencies.

Researchers of autobiography outline the following key features of the genre: the grammatical perspective of the work (i.e. past tenses, first or third person narration etc.), the identity of the self, and, the most significant one, self-reflection and retrospection. C. Bacon states, that the author, the narrator and the protagonist must share a common identity for the work to be considered an autobiography. However, the common identity is not necessarily identical (Bacon, 2016: 1). The self, constructed by the author, becomes the character in the story, but is not a completely factual representation of the author's past self. According to E. Bates, even the most detailed autobiographies have fictional elements: "There is, in fact, no dividing line between autobiography and fiction" (Bates, 1937: 9). Therefore, S. Doubrovsky introduced a term "autofiction" to define this type of life writing (Doubrovsky, 2004: 70). A. Hughes develops the topic by claiming, that "autofiction may be understood as a narrative modality that inhabits the referential space likewise colonized by autobiography proper, but at the same time offers a patently enriched and treated, hence fictionalized, and metamorphotic, version of the life-story of the autofictionneur" (Hughes, 2002: 569).

The key difference between autofiction and autobiography is that in autobiography real experience of the author is presented, while in autofiction the author bases the narration on the actual experience by adding some fictional, made up elements without caring too much about historical accuracy. Within this genre authors have more freedom to add or hide some details, simplify or amplify the narration focusing more on artistic essence of their work rather than on the precise detailed depiction of events. In an interview with Barnens bibliotek Ulf Stark said: "I thought it was fun to mix one's own childhood with 
stuff I made up. That is way I got a much larger childhood" (translated by A. Bernardini) (Stark, 2019).

Another feature characteristic of this type of fiction is distant-engaging-narration: that is a kind of narration, that adheres to the focalizer's point of view, but that employs a narrator speaking from a later moment in time (Bernardini, 2019: 5). The researcher applies the term "partially autobiographic novel" to define the idea of autofiction. I. Starovoit indicates that "the voice of the child is the voice of other in relation to the adult narrator, who is trying to reconstruct the childhood" (Starovoit, 2004: 182).

The very possibility of first person narration, including "autofiction", is connected with a person's ability to imagine oneself as "different", mentally view oneself with other's eyes. The author's "I" in these cases becomes a reader's metaphoric "You", enabling the reader to identify himself or herself with the narrating character.

However, both autobiography and autofiction are the forms of introspection and involve depicting thoughts, emotions and intentions. Moreover, the events and feeling experienced by the autobiographical character explain to an extend the way of the authors' self development, their past influence on present personality of the character - narrator - author.

A. Bernardini claims, that "among the many works Ulf Stark penned during his long career, there are some which display a retrospective attitude, mixing events, places and situations derived from Stark's early years with fictional elements" (Bernardini, 2019: 2). This "autobiographical inspiration" is particularly evident in the trilogy about Ulf and Percy.

Many details in Ulf Stark's novels, such as first person narration, name and surname of the protagonist (Ulf Stark), some geographic names and biographic facts prompt the reader to believe that the character, the narrator and the author are the same person. However, considering the major idea of U. Stark's prose: presenting person's identity formation experience, it is worth mentioning. A. Wyile, who states that often "in looking back on their youth, older narrators present their lack of experience with an irony fine-tuned by hindsight" (Wylie, 1999: 186). A. Bernardini emphasizes this characteristic of Stark's prose, where Ulf's often naive point of view is that of a child of the 1950s, but is presented to the reader by an arguably older and wiser narrator. "This "double perspective" is also applied to the ideological frame through which Ulf sees the world: while Ulf's point of view is fully imbued with the ideals that were at the basis of the Swedish model, the narrator seems to adopt a retrospective critical and ironic gaze, which reveals the contradictions and the limits of that model" (Bernardini, 2019: 6).
Very often it is the childhood, that forms a writer as a personality. In Ulf Stark's autofiction the author presents his way to literature by analyzing and presenting retrospectively to reader events, which influenced his choice and formed his identity as a writer. The past time and space in the analyzed novels is mediated through presentation of time markers (memories, metaphors, inscriptions, smells and sounds, which evoke certain associations), spaces (cave, home, tree house) and people (father, mother, friends, teacher) who greatly influenced the author's identity and his experience of becoming a writer.

To begin with, we must admit, that the phenomenon of recollection mostly hides in itself the actual objective description, drawing attention to metaphors as figures of thinking, as artistic models. Therefore the memory metaphors appear in the genre of recollection "not as a descriptive language, but instead as a constitutive one, revealing the subject first" (Assman, 2014: 159). The memory metaphors arise as milestones on Ulf's, the autobiographical character, way to literature. They are special flashes, which enlighten "the central points" (G. Bachelard) of the future great talent birth.

In the story, we trace symbolic content of memory metaphors, as for example, the typing machine, bought by Ulf. Another image-symbol is horizon. Gazing at it thirteen year old Ulf foresees the importance of his future creative activity: "Over there beyond the horizon, there is always something new. And it does not matter how long it takes to get there" (Stark, 2017: 68). Ulf's "then" time is characterized by a willful dynamics.

We may single out time points in the text, which serve as emotional background of the aouthor's childhood time and turn out as signals about future literary creativity. We may define them as time of occasion. For the autobiographical character the following events turned into such "occasions": teacher's persuasions, that Ulf has "inborn" writer's soul; a conversation in a bookshop with the seller, who managed to understand "what he needed"; being on the ship with Agneta and "a weird" failure in love. Every "time of occasion" is interpreted as a milestone on the way to future entering literary creativity. As an example of such life changing moment, we may view the episode, dealing with the book-shop seller's story, that books must tell about something "very personal", which is created from the heart.

An episode in the novel "Then I was simply Ulf" tells a story of Ulf's friend Symona and her grandfather. Symona's grandmother had died long ago, and once the girl came across her granny's old cookery book. The silent rereading of the recipes the day before journey to the house on Majya island is self 
tempering for the painful comprehension of the ocean of love memories. These notes are like yesterday for grandfather, however for Symona they are like bygone times. In such cases "the text imprint not only follows the thought, but also proceeds it like activation signal, like an instruction" (Assman, 2014: 225). On the island grandfather presented Symona a flowery dress, which her grandmother wore for the first date. With the help of the dress as a vivid memory metaphor times suddenly get closer.

The experience of childhood for the real author finished approximately four decades ago. This way "then" becomes "a reanimation, when a place revives a memory, and the memory revives the place" (Assman, 2014: 30). Category of time and space acquires philosophical content in the process of recollecting, because " $<\ldots$. past is indestructible $<\ldots>$ it continues existing, in long ago abandoned familiar places we come across the not lost time $<\ldots$. " (Chycherin, 1980: 162).

Speaking about presenting space in the novels, we must emphasise, that heterogenic imagined spaces of Ulf's character cannot be "measured" - they can only be "experienced". They are paramount for learning the life of the soul. In these mysterious spaces of loneliness "the flashes of passion are grown and its feats are being groomed there", they leave a deep trace, which "the soul is unwilling to erase from the memory" (Bachelard, 2004: 31).

One of the examples of such spaces is so called cave, which was in fact just a larder in the house, where Ulf's father, who was a dentist, kept sand to be used for sprinkling the driveway during winter. However, for the boy the landscape of his inner life could be opened only here. This makes reader also interested in the dark shelter under the staircase. Thoughts make Ulf feel cozy in the cave. Here he observes heaps of gold, diamonds and painted porcelain birds. Describing the cave space, the author pays attention to acoustic detail: "An immensely pleasant music was heard in the air. Calle Jularbo played "The stream murmuring in Avesta" (Stark, 2017: 12). In this space of loneliness Ulf could truly enjoy his fantasy. Outside it, the boy didn't want to leave his imagined world and told parents about the treasures he had seen. He even regretted not having gathered full socks of diamonds for his mother.

In the imagined spaces of Stark's story Ulf's inner freedom is accentuated as the nucleus of his creative "I". It perceptibly is projected onto the surface of childhood creativity - drawing first, literature after fourteen.

One more space, that is characteristic of childhood, was the tree house, were Ulf liked to spend time. It embodies a lively open time and space in the story, which determines the direction of the plot elements. The place on the top of the tree belonged to his brother, while Ulf used to sit five branches down. From this space, he observed nature filled with life.

Another significant space presented in the novels is home. Here the vivid memory metaphors fix the originality of the house since great-great grandfather's times. Naturally, it was associated with personalities of his parents and their role in Ulf's life. Thus, father's duties are directed to Ulf's future - to turn him into "someone". Father not always could comprehend son's behavior. For example, he couldn't appreciate the excitement caused by what had been seen in the cave. However, only once, when Ulf thought that his classmate Henning knew more about the sky, than his father, his faith in his all-knowing parent shook.

Mother used to cry when her son wrote poems in his notebook, which resembled the poetic forms of Garcia Lorka (she thought a psychologist should work with him). When Ulf was reading avidly "The Stranger" by Camus, his mother watched him with a worried sympathetic look. Many years later author's memory immerses itself into mother's inner world in order to comprehend it to the deepest: "Most of all she wanted me to be still a young, plump, obedient, cute child laughing all the time. But this could not be returned" (Stark, 2017: 98).

Fifteen-year-old Ulf leaves his spiritual home space to gain his own experience in the wide world and enter the open space of literature. Ulf didn't comprehend his time of going out into the wide world as an ordinary time. At the very entrance to the wide world the writer's experience, planned by fifteen-year old Ulf for future, seemed almost perfect.

Depiction of smells plays a significant role in the novels. The most interesting fact is that the problem of smell attracted Ulf's teenager attention even in psychoanalytical aspect: " $<\ldots>$ I was trying to remember Piya's smell. But how can one possibly remember a smell?" (Stark, 2008: 66). The thing is that smells conjure up certain real pictures in character's imagination. The smell imprint can be interpreted as a prediction sign on the way of a unique talent formation. Hence these smell impressions can be considered as the key to recalling the information about childhood events.

Friendship and love are two forms of relationship which significantly influenced the formation of Ulf's character and his identity as a writer. He had a very clever and interesting friend. Unfortunately, this friendship was short lived. Henning couldn't understand the necessity to talk about the kisses with girls, while it was strange for Ulf, that his friend wasn't interested in them. He also disliked some of the habits of his geography and astronomy savvy classmate, 
as well as the fact, that Henning smiled too much and often without a reason, or pulled up his trousers too often, especially when he was about to sit down. Despite this, Ulf admired Henning's immense intellect and enjoyed communicating with him.

As to love, Ulf believed that he needed one, because every true writer or poet had an unhappy love. The same happened in his life. Ulf and Agneta liked talking about Universe, art and their preferences. Nevertheless, Ulf wasn't surprised, when she left him accepting Kore's proposition to go to the bar for a snack. During one of the meetings with Agnetta he remembered a science fiction poem "Aniara" by a Swedish author Harry Martinson. It told about a space ship roaming the space as it lost its course. Ulf felt the same. Why did Agnetta smiled gently to Kore when he was saying nonsense? Why did she preferred Kore, who was wearing sandals even though she hated boys wearing ones? These questions made Ulf suffer, but at the same time served as inspiration to create further in life. He reassured himself that every true author must have an experience of unhappy love that will feed his fantasy and inspire him to creativity.

Imagination is paramount for future creative activity of a writer, therefore in the autofiction novels by Ulf Stark this topic is widely described. According to $Z$. Freud, creative activity resembles the behavior of a plying child. It places things, with which it plays, in a new order, pleasant to it, using emotions. In the process of a game, the child is oriented to a real world and adjusts the objects of its imagination to it: "Nothing but the very adjustment distinguishes the child's "game" from "imagining"” (Freud, 2002: 109).

Ulf's, the character's, imagination can be described as more than extravagant. For example, once inspired by a conversation with his friend Henning, he saw a dream about a planet as if vice versa, which he later described in detail. Instead of drinking coffee, his parents spit it back into cups, his father called himself a mother, and his mother called herself a father. Ulf was impressed with red grass. Black seagulls were flying in the white sky with blue clouds. Time flew backwards here. Ulf's important question about his dog was greeted with mother's answer that he used to have a white dog long before mother and father were born. Ulf woke up and found himself at home in his bed. Here near his parents, stood a bald alien (he wanted to make sure that Ulf was really at home and his parents were taking care of him). Even now, he still remained on the planet as if vice versa. Parents were extremely concerned about Ulf's health, as he addressed "mother" to his father. Lying in the bed Ulf watched excitedly the black dog which he would get when he became old.
Episodes from other Stark's works illustrate the fragile and at the same time active imagination of the autobiographical character. An episode in the novel "My friend Perci, Boffalo Bill and Me" tells about granny, who used to soak trout eye, saying that it was the most delicious in the fish. During such moments, Ulf imagined "horror films". In another episode of the story, when Piya was skillfully cutting a pike, Ulf deeply sympathized with the poor fish. He focused on the pike's dead heart, lying near him but still beating: "My heart was also throbbing so hard, it nearly got out of my chest" (Stark, 2008: 42).

Another episode, that could be defined as a time of occasion that inspired Ulf to involve his imagination was the art lesson, when teacher told students to draw cows. Unlike his classmates' drawing, where white, red, black and white cows were shown, Ulf's cow was blue.

Later, the teacher mentioned Picasso and brought to the class an album with the picture of cows by a Byelorussian-French artist Shagal. She talked about these paintings as about "pieces of art, which express something more than trivial everyday feelings. They render the state of our soul. Exactly as Ulf's cow" (Stark, 2017: 25). In the analyzed episode, it is hard to believe the teacher's words about charisma both for Ulf and the reader. As both know that Ulf's blue cow is just the result of the lost red paint. Still, this episode is introduced to decode the author's intention. U. Stark wanted to emphasize, that this occasion did boost his belief in own creative genius.

Reader comes across numerous episodes in the text depicting Ulf's attitude to literature. The boy adores reading poetry. He carries books with him when he leaves home to travel. He is trying to read them at any circumstances. The reader may guess that the rhythm of poems he read penetrated his consciousness. Once, he was even trying to remember the poem "Lonely thoughts" by Wernher von Geidenstan.

Conclusions. Autofiction as a genre of life writing is characterized by distant narration structures and combination of factual elements with fictional reconstruction of events from author's life. The main idea of this type of works is to describe and share with the reader the key stages of the author's identity development by depicting emotions, thoughts and impressions of childhood, that became crucial for author's adult personality. Ulf Stark's works "Then I was simply Ulf" and "My friend Perci, Buffalo Bill and me" may be referred to as vivid examples of autofiction. In these texts readers familiarize themselves with major characters (parents, teacher, book seller, friend, girlfriend) and life turning points (adventures, travels, school experience), which later served as 
steps towards Stark's literary career. By analyzing these works readers find out about social and cultural factors, which determined Ulf Stark's career choice and influenced his identity as a writer. The central place is occupied by childhood imagination as the driving factor in creative activity. Memory metaphors and significant time and space markers also contribute to the key idea development of the works.

\section{BIBLIOGRAPHY}

1. Ассман А. Простори спогаду. Форми та трансформації культурної пам’яті. Київ : Ніка-Центр, 2014. 440 с.

2. Башляр Г. Избранное: Поэтика пространства. Пер. с франц. Москва : РОССПЭН, 2004. 376 с.

3. Констанкевич I. Українська проза першої половини XX століття : автобіографічний дискурс. Луцьк : ВежаДрук, 2014. 420 с.

4. Лежен Ф. Я в некотором роде создатель религиозной секты... Перевод Е. Галстовой. Иностранная литература. 2001. № 4. C. 257-264.

5. Марченко Н. Автобіографія дитинства у межах біографічного дискурсу. Украӥнська біографістика. 2012. Вип. 9. С. 90-109. URL: http://nbuv.gov.ua/UJRN/ubi_2012_9_5.

6. Старк У. Тоді я був просто Ульф. Перекл. Г Кирпа. Львів : Видавництво Старого Лева, 2017. 128 с.

7. Старк У. Мій друг Персі, Буфало Біл і я. Перекл. Г Кирпа. Вінниця : Тези, 2004. 208 с.

8. Старовойт І. Автобіографія дитинства. Вісник Львівського університету. Серія «Філологічна». Львів. нац. ун-т імені Івана Франка, 2004. Вип. 33 : Теорія літератури та порівняльне літературознавство. Ч. 1. С. 178-185.

9. Фройд 3. Поет і фантазування. Антологія світової літературно-критичної думки ХХ століття / за ред. М. Зубрицької. Львів : Літопис, 2002. С. 109-116.

10. Чичерин А. Ритм образа. Стилистические проблемы. Москва : Советский писатель, 1980. 396 с.

11. Bacon C. The Genre of Autobiography: Definition and Characteristics. May, 2013. URL: https://owlcation.com/ humanities/TheGenreofAutobiography.

12. Bates E. S. Inside Out: An Introduction to Autobiography. New York : Sheridan House, 1937. 687 p.

13. Berardini A. "I'm Going to be a Businessman": Learning about Money and Class in Ulf Stark's Ulf and Percy Trilogy. Barnboken. Journal of Children's Literature Research. 2019. Vol. 42. P. 1-16.

14. Cardel K., Douglas K. Telling tales. Prose studies. 2013 V. 35. P. 1-6.

15. Doubrovsky S. Dictionary of Literary Biography, Volume 299: Holocaust Novelists / Ed. Efraim Sicher. Ben-Gurion University of the Negev. Gale, 2004. P. 70-76.

16. Hughes A. Recycling and Repetition in Recent French Autoficion: Marc Weitzmann's Doubrovskian Borrowings. The Modern Language Review. 2002. Issue 97.3. P. 566-576.

17. Intervju med Ulf Stark (Interview with Ulf Stark). Barnens bibliotek. URL: www.barnensbibliotek.se/Författare/ FörfattareAÖ/UlfStark/ tabid/271/Default.aspx (Accessed 5 March 2019).

18. Lierop-Debrauwer H. How the Reader Matters. Autobiographies of Childhood for Young Readers. European Journal of Life Writing. 2018. Vol. VII. P. 1-16.

19. Wyile A. Expanding the View of First-Person Narration. Children's Literature in Education. 1999. Vol. 30. № 3. P. 185-202.

\section{REFERENCES}

1. Assman A. Prostory spohadu. Formy ta transformatsii kulturnoi pamiati [The space of memory. Forms and transformations of cultural memory]. Kyiv: Nika-Centre, 2014. 440 p. [In Ukrainian]

2. Bachelard G. Izbrannoe: poetika prostranstva [Selected essays: Poetics of space]. Translated by N. Kulish. Moscow: Russian political encyclopedia, 2004. 376 p. [In Russian].

3. Bacon C. The Genre of Autobiography: Definition and Characteristics // https://owlcation.com/humanities/ TheGenreofAutobiography, May, 2013.

4. Bates E. S. Inside Out: An Introduction to Autobiography. New York: Sheridan House, 1937. 687 p.

5. Berardini A. "I'm Going to be a Businessman": Learning about Money and Class in Ulf Stark's Ulf and Percy Trilogy. Barnboken. Journal of Children's Literature Research. vol. 42, 2019, pp. 1-16.

6. Cardel K., Douglas K., Telling tales. Prose studies, V. 35, Issue 1 (April 2013). pp. 1-6.

7. Chicherin A. Ritm obraza. Stilestichekie problemy [Rhythm of the image. Stylistic problems]. Moscow: Soviet writer, 1980. 396 p. [ In Russian].

8. Doubrovsky S. Dictionary of Literary Biography, Volume 299: Holocaust Novelists. Ed. Efraim Sicher. Ben-Gurion University of the Negev: Gale, 2004. 70-76.

9. Freud Z. Poet i fantrazuvannia [Poet and fantasy]. Translated by I. Harasym. Anthology of world literary and critical thought of the XX'th century, edited by Maria Zubrytska. Lviv: Litopys, 2002. pp. 109-116 [In Ukrainian].

10. Hughes A. Recycling and Repetition in Recent French Autoficion: Marc Weitzmann's Doubrovskian Borrowings. The Modern Language Review. Issue 97.3. 2002. Pp. 566-576.

11. "Intervju med Ulf Stark" [Interview with Ulf Stark]. Barnens bibliotek, www.barnensbibliotek.se/Författare/ FörfattareAÖ/UlfStark/ tabid/271/Default.aspx. Accessed 5 March 2019. [In Sweddish]

12. Konstankevych I. Ukrainska proza pershoi polovyny XX stolittia: avtobiohrafichnyi dyskurs [Ukrainian prose of the first half of the XX'th century: autobiographical discourse]. Lviv: Vezha-Druk, 2014. 420 p. [In Ukrainian]. 
13. Lejeune Ph. "Ya v nekotorom smisle sozdatel religioznoi sekty..." [I am a kind of religious sect founder...]. Translated by E. Galtsova, Foreign literazture, 2001, № 4, pp. 257-264 [ In Russian].

14. Lierop-Debrauwer, H. How the Reader Matters. Autobiographies of Childhood for Young Readers European Journal of Life Writing, Vol VII, 2018., pp. 1-16.

15. Marchenko N. P. Avtobiohraphiya dytynstva u mezhakh biographichnoho dyskursu. [Autobiography of childhood within biographical discourse]. Ukrainian biography studies 2012. Issue 9. P. 90-109. Accesshttp://nbuv.gov.ua/UJRN/ ubi_2012_9_5. [In Ukrainian].

16. Stark U. Miy Druh Persi, Buffalo Bill i Ya [My Friend Percy, Buffalo Bill and I]. Translated by Halyna Kyrpa, Vinnytsia: Thesis, 2008. 208 p. [In Ukrainian].

17. Stark U. Todi ya buv prosto Ulf [Then I was simply Ulf]. Translated by Halyna Kyrpa. Lviv: Vydavnytstvo Staroho Leva, 2017. 128 p. [In Ukrainian].

18. Starovoit I. Avtobiohrafia dytynstva [Autobiography of childhood]. The bulletin of Lviv university. Philological series. Issue 33. Literary theory and comparative literature. Part 1. Lviv Ivan Franko national university, 2004, pp. $178-185$. [In Ukrainian].

19. Wyile A. Expanding the View of First-Person Narration. Children's Literature in Education, vol. 30, № 3, 1999, pp. 185-202. 